Article

\title{
Social Impact Bonds for a Sustainable Welfare State: The Role of Enabling Factors
}

\author{
Rosella Carè *(D) and Riccardo De Lisa \\ Department of Economics and Business, University of Cagliari, Viale S. Ignazio, 17-09123 Cagliari, Italy; \\ delisa@unica.it \\ * Correspondence: rosella.care@unica.it
}

Received: 30 April 2019; Accepted: 16 May 2019; Published: 21 May 2019

\begin{abstract}
The financial crisis has put pressure on governments throughout the world to reduce deficits with severe budgetary cuts in many welfare areas by reinforcing the need to modernize social policies and optimize their effectiveness and efficiency. Social impact bonds (SIBs) have rapidly become one of the most innovative financial schemes used by governments to privatize the upfront costs of welfare interventions by reducing taxpayer expenditure. Our analysis focuses on healthcare impact bonds (HIBs) that correspond to the adaptation of SIBs to health programs and are considered to be a viable way to fund out-of-pocket and preventive programs, especially considering the recent cuts to public healthcare expenditure. By using an in-depth qualitative analysis of existing practices based on a multiple case study approach, this study contributes to the ongoing debate on the role of SIBs for the future sustainability of welfare systems by proposing reflections and indications for the scalability and replicability of SIBs. With respect to the existing literature, this paper provides a theorization of the main scaling ingredients to be considered for the development of the SIB market as a supporting financial approach for new and emerging welfare needs by also proposing suggestions and insights and serving as a guide for scholars and practitioners.
\end{abstract}

Keywords: impact investing; social impact bond(s); healthcare impact bond(s)

\section{Introduction}

The financial crisis has put pressure on governments throughout the world to reduce deficits with severe budgetary cuts in many welfare areas by reinforcing the need to modernize social policies, optimize their effectiveness and efficiency, and the way they are financed [1].

Health protection activities (among other social protections) have been subject to close scrutiny from policymakers [2] and governments worldwide have increased their interest in outsourcing the funding and delivery of welfare services with the aim to reduce public expenditure deficits [3]. Public spending on health fell or slowed in many countries between 2007 and 2012. In 2007, on average, health comprised 13\% of total public spending in the European Region while between 2007 and 2011 the health share of public spending fell at some point in many countries [4]. Recently, the Social Business Initiative of the European Commission and the G8 Social Impact Investment Taskforce have highlighted the numerous benefits that social finance instruments and mechanisms, especially social impact bonds (SIBs), could bring to welfare systems.

Considered as an emerging social policy instrument [5] able to fund innovative social programs while generating profits for investors and savings for governments [6], SIBs have rapidly become one of the most innovative financing schemes [7]. The origin of SIBs dates back to the introduction of payment-by-result $(\mathrm{PbR})$ schemes by the UK government in 2009 [3] and appear rooted around the three typical elements of the New Public Management repertoire: contracting, performance measurement, and Public-Private Partnerships (PPPs) [8,9]. Nevertheless, in contrast to a traditional PbR scheme, 
the financial risks are not placed on the service provider or on the commissioner but are transferred to the social investors that finance the deal [10].

From a theoretical point of view, SIBs allow the government to privatize the upfront costs of social interventions and the associated risks by reducing taxpayer expenditure in the short-term as well as eliminate the risk of public money being spent on initiatives that do not deliver the desired outcomes [11]. Savings in public sector spending can occur through a reduction in future expenditure due to the improved effectiveness of an existing service, or through savings related to interventions that would have otherwise been a lingering problem for governments and taxpayers such as the costs of welfare provision [12].

During the last few years, SIBs have been used in several countries as a widely hailed financial innovation for welfare programs [13]. Since the first program launched in Peterbourgh (UK) in 2010, SIBs have raised a total amount of $\$ 431$ million through 132 initiatives distributed across 25 countries (Argentina, Australia, Austria, Belgium, Canada, Cameroon, Congo, Colombia, Germany, Finland, France, Japan, India, Israel, the Netherlands, New Zealand, Peru, Portugal, South Africa, South Korea, Sweden, Switzerland, Uganda, the United Kingdom, and the United States) by targeting social issues such as criminal justice, homelessness, child and family welfare, early childhood education, workforce development, health, poverty and environments, and adults with complex needs [14].

However, despite this considerable success, previous works have suggested the need for a systematic analysis of the benefits, costs, risks, and contractual schemes in SIB projects in order to understand if and how they could effectively contribute to the welfare issues and what the key dimensions need to be considered for their scalability.

Moving forward from these considerations, this paper intends to contribute to the ongoing debate on the role of SIBs for the future sustainability of welfare systems by proposing reflections and indications for their scalability and replicability by using an in-depth analysis of existing practices trough a multiple case study approach. In doing this, we focused on healthcare impact bonds (HIBs), which correspond to the adaptation of these current examples of SIBs in recidivism and child removal into new health programs and interventions [15]. Considered as a viable way to fund out-of-pocket programs, currently developed HIBs promote preventive programs with the promise of future public expenditure savings [16].

In particular, HIBs represent an innovative financial approach to fund evidence-based programs, encourage investments in cost-saving preventive services in order to reduce the need for more costly remediation, and fill the market gap between the private and public sector [15].

Specifically, this paper provides an overview of the state of the art of the most relevant literature regarding social impact bonds and a detailed analysis of recent contractual models by focusing on health protection activities (among other welfare areas) that have been subject to close scrutiny from policymakers and governments who have increased their interest in outsourcing the funding and delivery of services with the aim to reduce public expenditure deficits [3,17]. The work was developed around three main parts: (i) a literature review of academic and practitioner contributions regarding SIBs; (ii) the analysis of four existing HIBs by using a qualitative approach; and (iii) a conceptual framework and a roadmap for scalability and replicability.

With respect to the existing literature, this paper provides a theorization of the main scaling ingredients to be considered for the development of the SIB market as a supporting financial approach for new and emerging welfare needs. The work contributes to the ongoing debate on the role of private capital for public services and by focusing on the possibility of alternative sources of funding for welfare systems by proposing suggestions and insights and serving as a guide for scholars and practitioners. The remainder of the article is structured as follows. In the next section, we provide a literature overview; then, we present our methodological approach, research design and main findings; and finally, we conclude by providing a series of enabling factors and discussing the implications of our study. 


\section{Background}

Previous works on SIBs have widely recognized that a series of aspects remain to be addressed for the development of a SIB market that is able to support welfare needs and provide support to public sustainability issues.

\subsection{Collaborations and Contractual Schemes}

SIBs embody a cross-sector collaboration in shared value processes in the form of an innovative partnership for sustainability that can be defined as a public-private, collaborative, and outcome-based contracts incorporating impact finance logics [18].

The SIB model represents a new PPP approach designed around a series of contracts between the involved parties in the commissioning and provisioning of social services.

The complex heterogeneity of stakeholders that can be involved in a SIB project has been confirmed by the different contractual models that have been developed around the globe. From a contractual point of view, several authors have pointed out that currently, several SIB models exist. In this vein, Clifford and Jung [13] distinguished between three main models. The first, in which a special purpose vehicle (SPV) is established as a "core contracting vehicle" that receives funds from the investors, enters into a contract to deliver public services with the commissioner, and contracts out that delivery to service providers. The second model is where the SPV is formed, but acts as a contract manager, with the commissioner entering into a contract directly with the provider; and the third, named as the managed network, is where a project manager acts as the hub of the network [13]. By reviewing existing HIBs practices, Fraser et al. [10] highlighted that three different models could be identified: (1) the direct provider SIB model; (2) SIB with a SPV; and (3) a social investment partnership (SIP) model, where by using the same SPV, several SIPs can be set up by providing the same service in different places and by repaying investors by using other performance targets [8]. So and Jagelewski [19] discussed the two main SIB models (SPV and direct contracting) and clarified that the delivery organization of the SIB could be arranged through a social service provider or a special purpose vehicle (SPV) that provided increased flexibility and risk mitigation. In particular, by using the SPV model: (a) the commissioner contracts for outcomes with the SPV and payments are made directly to the SPV if the scheduled outcomes are achieved; (b) the SPV contracts the service providers and (eventually) a social finance intermediary to set out advisories or other kind of services; (c) investors typically invest directly into the SPV by assuming ownership; (d) the SPV is managed by a board of directors that is comprised of investor representatives; and (e) the board is in charge of monitoring the SIB program and considers the service providers directly accountable to the performance standards scheduled in their contracts [19].

\subsection{Alignment of Interests and Principal Agent Issues}

Usually, SIBs provide additional non-core social services, rather than serving as substitutes for existing services, and enable innovation in tackling persistent social problems by generating economies through scaling and the use of effective performance management [20].

The best candidates for this type of funding model are programs with large upfront costs that serve a large number of people and have a strong evidence base. From the public sector perspective, the involvement of investors makes SIBs a unique form of public sector contracting that not only offers risk transfer, but better performance management, resulting in better social outcomes [21].

By using the SIB model, governments are more likely to be willing to spend money on social or healthcare programs to improve people's lives by sharing the related risks with the private sector. A well-defined SIB creates an incentive structure that aligns the interests of governments, investors, and service providers around the delivery of a pre-agreed set of outcomes [22-24].

The question of the "Alignment of Interests" was further clarified by Maier and Meyer [25], who highlighted that like any other kind of contract, a SIB could only bring a partial alignment of 
the main actors' interests due to the outcome-based incentives, as each actor continues to also have interests that differ from those of the others.

SIBs could potentially exacerbate the public sector's principal-agent problem, which exists even in traditional performance-based contracts, where the principal, that is, the public commissioner issuing and managing the contract, must rely from a distance on its agent by using taxpayer dollars appropriately (or not) to deliver services effectively (or not) [26].

\subsection{Evaluation and Public Savings}

Moreover, savings may not be a sure outcome of SIBs relative to other ways of contracting or delivering a service. Transaction costs associated with a SIB are higher relative to any other funding option [20,22,27,28]. With regard to transaction costs, Pandey et al. [29] used Spiller's "transaction cost theory of regulation (TCR)" framework [30,31], which enables "opening of the black box of regulation" which governs public-private contracts to underline how public-private contracts also show the problem of the contractual hazards of governmental opportunism and third-party opportunism. In a SIB contract, the government's principal-agent problem will be further stressed by the presence of an additional layer of agents: the social finance intermediary arranging the initial funding and the delivery of services [26].

From a governance perspective, McHugh et al. [32] (p. 251) clarified that the absence of a direct relationship between the service provider and government potentially generated information asymmetries in favor of the provider by reducing the possibility of government to act in case of malpractice.

In the SIB model, the desired goals of each party involved could differ from one another. In particular, by immediately receiving the upfront capital necessary for the delivery of the activities, the service provider may be less motivated than impact investors to achieve the scheduled outcomes. On the other hand, socially motivated investors receive their returns only after a rigorous evaluation of the outcomes achieved by an independent evaluator. Simultaneously, information asymmetries may occur between the service provider and both investors and commissioners in terms of the appropriateness of the outcome metric used for the evaluation of success. A SIB contract introduces new actors into the "commissioner-provider" relationship and establishes new rules for the governance of specific services, thus distributing risk among actors in new ways [10].

Academics and professionals have widely identified in the development of a set of robust evaluation models one of the main drivers for the development of the SIB market by suggesting that further studies are required to investigate critical matters and technical aspects [10,33]. Flynn et al. [34] and Wilson et al. [35] underlined the general scarcity of successful evaluation practices by noting the importance of identifying high-quality evaluation approaches. However, measurement is more than only metrics, and the development of a standard evaluation model should not leave out a clear understanding of what is important to measure for each stakeholder. In this sense, from a public sector perspective, the effective evaluation of the level of savings could be done using the value for money (VFM) approach based on the estimation of the project's future financial and nonfinancial benefits [36]. VFM was initially developed in the United Kingdom and has been adopted in various forms as part of the public-private partnerships (PPPs) procurement [37]. The VFM is generally estimated by using a comparison against a public sector comparator (PSC). Nevertheless, calculating the PSC is further complicated by the need to estimate and discount the cash flows in addition to calculating the cost of risks transferred to the private sector [38]. From this perspective, it may not be possible to effectively assess the claimed benefits of this kind of contract in terms of VFM and the final costs of a SIB contract may not be completely identified and measured a priori [39].

The concept of VFM is profoundly different depending on whether the public or private sector is considered. In the public sector, VFM is strongly affected by quality and performance together with cost minimization, while in the private sector, VFM is driven by profit maximization and all private stakeholders are driven by risk/return optimization goals [40]. Finally, cost-benefit should be 
considered in designing and implementing SIBs. Cost-benefit analysis seeks to assess the net value of a policy or project to society as a whole, and the evaluation of nonmarket impacts is an essential element of the process. The purpose of benefits evaluation is to understand whether an SIB's benefits exceed its costs. Generally, benefits can be classified into (i) cashable savings to the commissioner, (ii) non-cashable benefits to the commissioner, (iii) cashable savings to other public sector bodies, (iv) non-cashable benefits to other public sector bodies, and (v) social benefits [39,41].

The literature dealing with the financial valuation of SIBs has mainly focused on the posterior estimation of social impact and on a mere contextual cost-benefit analysis for the public sector, but a prior financial formulation of these assets would be useful in attracting potential investors [42]. Fraser et al. [10] (p. 14) highlighted the main difficulties in the process evaluations of SIBs such as the difficulty of agreeing what should be measured, by whom, and how often as well as the time needed to establish the contracts among the parties, and pointed out the challenges related to the intrinsic complexity of SIBs, including the novelty of the process and the provision of innovative services.

\section{Research Design}

\subsection{Methodological Approach}

This study employed an exploratory and qualitative approach to investigate previous SIB experiences. In detail, a grounded theory methodology based on multiple case studies [43] is mainly appropriate for the description of complex contemporary phenomena within their contexts [44] (p. 544) and for the provision of a unique means of developing theory by utilizing in-depth insights of empirical phenomena [45]. The grounded theory method offers a logically reliable set of data collection and analysis procedures aimed to develop theory [46] by facilitating the identification of regular patterns in data [47]. As clarified by Dooley [48], theory building requires the constant comparison of data and theory [47] and a process of continuous refinement between theory and practice [49]. In this sense, case study research, due to the ability to embrace both quantitative and qualitative data, and embrace multiple research paradigms, can contribute in a holistic way to all phases of theory development [48]. For these reasons, a grounded theory methodology based on multiple case studies (MCS) [43] was used to analyze four existing HIBs with the aim to provide a unique analysis of the enabling aspects that allow governments to consider this emerging funding model as a support for their welfare systems. From a methodological point of view, MCS enable building more robust and generalizable theory than a single case can [43] and are appropriate for describing complex contemporary phenomena within their contexts [50].

The sampling method, which can be considered to be a convenience sample, is intended to maximize efficiency and validity, both internally and externally [51]. External validity (or generalization) represents one of the main issues in conducting case study research. In this sense, Yin [52] refers to the term "analytical generalization" to describe the process by which the findings of a case study can be generalized to build a theory. Moreover, with regard to the sample composition, the following criteria were considered: (1) scientific interest (each case highlights a specific aspect of the phenomena); (2) transparency (only cases with adequate availability of information were selected); and (3) reliability and trustworthiness (only cases with certainty regarding data and information were considered).

The final sample was composed of information-rich cases able to manifest the phenomenon of interest intensely (but not extremely) [53] and cases were selected for their relevance to the research purpose.

In selecting our cases, we focused our analysis on HIBs due to fact that, from a welfare perspective, governments with limited resources frequently reduce healthcare expenditure and particularly their spending on preventive healthcare with no evident immediate health impact [54].

Moreover, cases were selected by considering the characteristics of the countries in which they have been developed. In particular, HIB schemes have been currently developed in nine different countries (Congo, UK, Canada, USA, Australia, Netherlands, Japan, Israel, India, Cameroon, New Zealand), 
but only two (the UK and Canada) have a national health system based on a "single payer" mechanism and a universal health model, which has led to this particular kind of financial scheme being seen as a viable alternative to the traditional publicly funded models of service provisions. The selected sample provides the opportunity to analyze different aspects that can be derived from the projects' heterogeneity. Table 1 provides an overview of the selected case studies.

Table 1. Selected cases.

\begin{tabular}{|c|c|c|c|c|c|}
\hline SIB Name & Country & Healthcare Issues & Target Population & Launch Date & Capital Raised \\
\hline $\begin{array}{l}\text { Community } \\
\text { Hypertension } \\
\text { Prevention } \\
\text { Initiative }\end{array}$ & Canada & Hypertension & $\begin{array}{l}7000 \text { prehypertensive older } \\
\text { adults }(60+) \text { in Toronto } \\
\text { and Vancouver. }\end{array}$ & October 2016 & $\mathrm{C} \$ 2 \mathrm{M}$ \\
\hline $\begin{array}{l}\text { Mental Health } \\
\text { and Employment } \\
\text { Partnership }\end{array}$ & UK & $\begin{array}{l}\text { Mental health and } \\
\text { employment }\end{array}$ & $\begin{array}{l}2500 \text { people with severe } \\
\text { mental illness (typically with } \\
\text { a diagnosis of psychosis, } \\
\text { such as schizophrenia, bipolar } \\
\text { disorder, or severe depression } \\
\text { or anxiety) currently in contact } \\
\text { with statutory mental } \\
\text { health services. }\end{array}$ & January 2016 & $£ 0.4 \mathrm{M}$ \\
\hline Reconnections & UK & Social isolation & $\begin{array}{l}\text { At least } 3000 \text { people aged } \\
50 \text { years and over classified on } \\
\text { the UCLA loneliness scale } \\
\text { (a common loneliness measure) } \\
\text { as } 8 \text { to } 12 \text { (though it is expected } \\
\text { that most clients will be } 65+\text { ). }\end{array}$ & July 2015 & $£ 0.85 \mathrm{M}$ \\
\hline Ways to Wellness & UK & Social prescribing & $\begin{array}{l}11,000 \text { people with long-term } \\
\text { health conditions such as lung } \\
\text { disease, diabetes and asthma. }\end{array}$ & March 2015 & $£ 1.7 \mathrm{M}$ \\
\hline
\end{tabular}

Source: Our elaboration from the Social Finance Database [14].

\subsection{Data Sources, Research Protocol and Coding Procedures}

Data were drawn from multiple sources (i.e., websites, reports, and secondary sources) with the main aim of increasing the construct validity by encouraging convergent lines of inquiry [52].

To ensure the reliability of our study, and consequently minimize errors and bias, a research protocol was designed [52]. The protocol defined our sources of data, our data analysis procedures, and the reporting outline. Using the research protocol, the data were recorded and examined. Following the suggestions of Strauss and Corbin [55] and of Nag and Gioia [56], we structured our analysis in light of both contextual factors (emerging from cases) and prior theorization and by creating a set of four dimensions of analysis to develop an emergent, inductive model.

As we collected information about our case studies, we also began to analyze them, adhering to the guidelines specified in our research protocol.

These steps helped to guide the focus of additional data collection [47]. We also cycled between the consultation with the most relevant literature and data analysis as guides for the development of our dimensions of analysis. As we discerned information that was similar, we collated them into our dimensions or sub dimensions of analysis (Figure 1).

As described in Figure 1, in this study, we considered four basic dimensions of analysis in order to examine and characterize the main aspects that led to the development of SIBs: contractual schemes, involved parties, financial aspects, and governmental policy/legal framework.

As the within-case analysis proceeded, we also began cross-case analysis, which aimed to compare emergent similarities or differences. In the second step, we proceeded with the composition of our case histories [43]. 


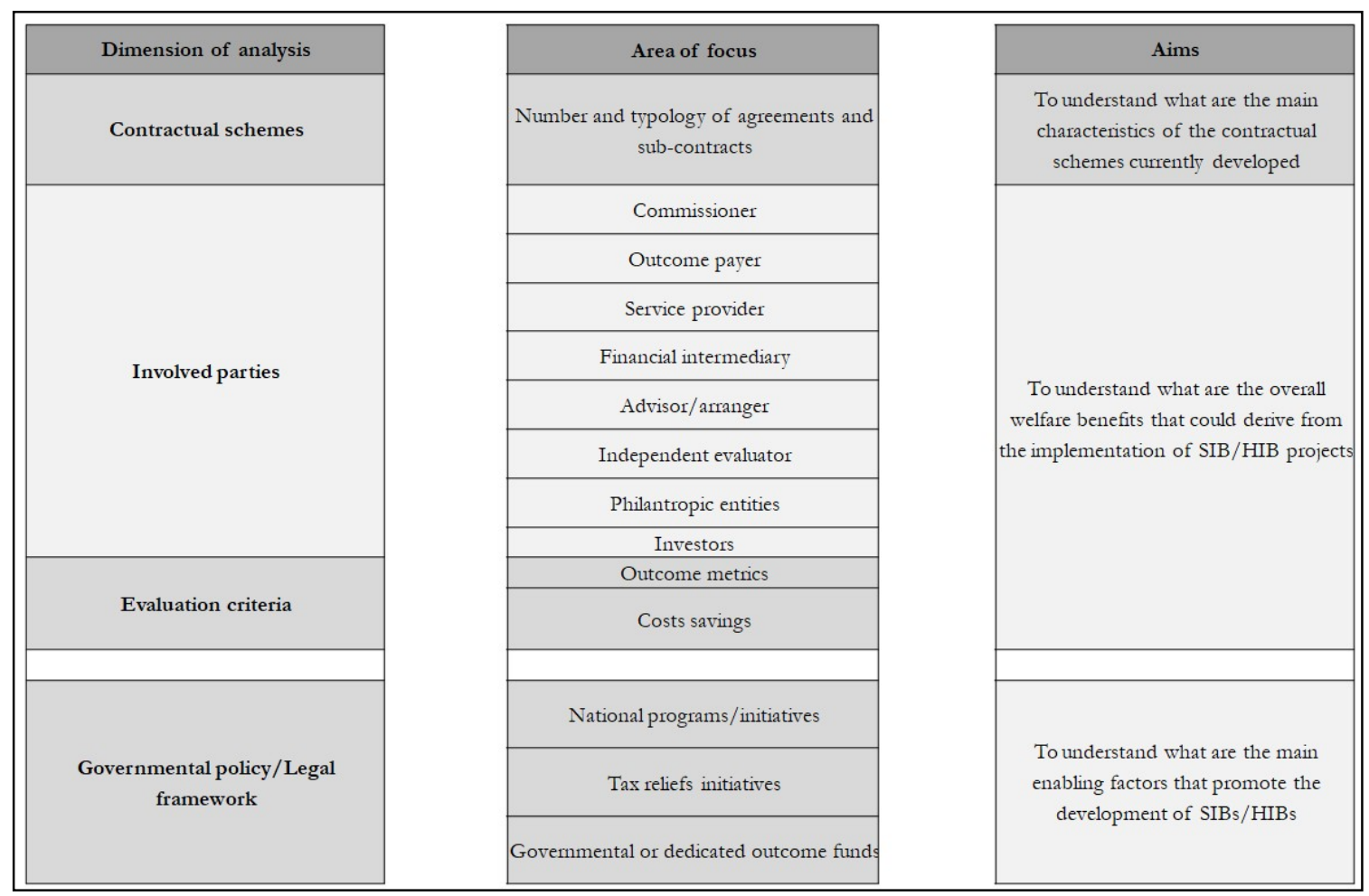

Figure 1. Dimensions of analysis. Source: Our elaboration.

\section{Case Studies}

We analyzed four HIBs. The first project (the Heart and Stroke Healthcare Impact Bond) was launched in Canada in 2016, while the others (Mental Health and Employment Partnership, Reconnections, and Ways to Wellness) were launched in the UK, which currently represents the country with the highest number of SIBs initiated. The sections below provide an overview of our case studies.

\subsection{The Heart and Stroke Healthcare Impact Bond}

The first Canadian SIB in preventative health was launched in October 2016 by the Public Health Agency of Canada [57,58]. The Heart and Stroke Healthcare Impact Bond (hereafter H\&S) is based on an outcomes-payment approach to fund a lifestyle change program, the Community Hypertension Prevention Initiative (CHPI), with the aim to prevent pre-hypertensive seniors progressing to full hypertension [58]. The program was developed in collaboration with the MaRS Discovery District and Heart and Stroke Foundation and has been offered in communities across Toronto since June 2017, and Vancouver since October 2018 [57,59]. The H\&S HIB has been promoted under the form of a community hypertension prevention initiative and was launched by the Heart and Stroke Foundation using a SIB model to deliver services to residents of Ontario and British Columbia aged 60 or older through health coaches, online tracking tools, and referrals to community resources such as exercise clubs and cooking classes [59]. The main involved partners are summarized in Table 2.

The initiative enrolled 7000 pre-hypertensive Canadians in a six-month program to help them adopt healthy behaviors and control their blood pressure [16]. The project was developed at the federal level and the Heart and Stroke Foundation-in collaboration with the MaRS Centre for Impact Investing and the Public Health Agency of Canada-attracted 11 investors [59]. The Heart and Stroke Foundation is a Canadian charity focused on preventing heart disease and stroke, which represent the main causes of hospitalization and death for Canadians. Investor capital to HSF and outcome payments to investors flow through a trustee (Figure 2). 
Table 2. Involved partners in the H\&S HIB.

\begin{tabular}{ll}
\hline Outcome Founder & Public Health Agency of Canada (PHAC) \\
\hline Service Provider & Heart and Stroke Foundation of Canada \\
\hline Independent evaluator & The Social Research and Demonstration Corporation \\
\hline Investors & Foundations, high-net-worth individuals, and companies \\
\hline Project development \& performance advisor & MaRS Centre for Impact Investing \\
\hline Legal advisor & Miller Thomson LLP \\
\hline
\end{tabular}

Source: Our elaboration from publicly available information.

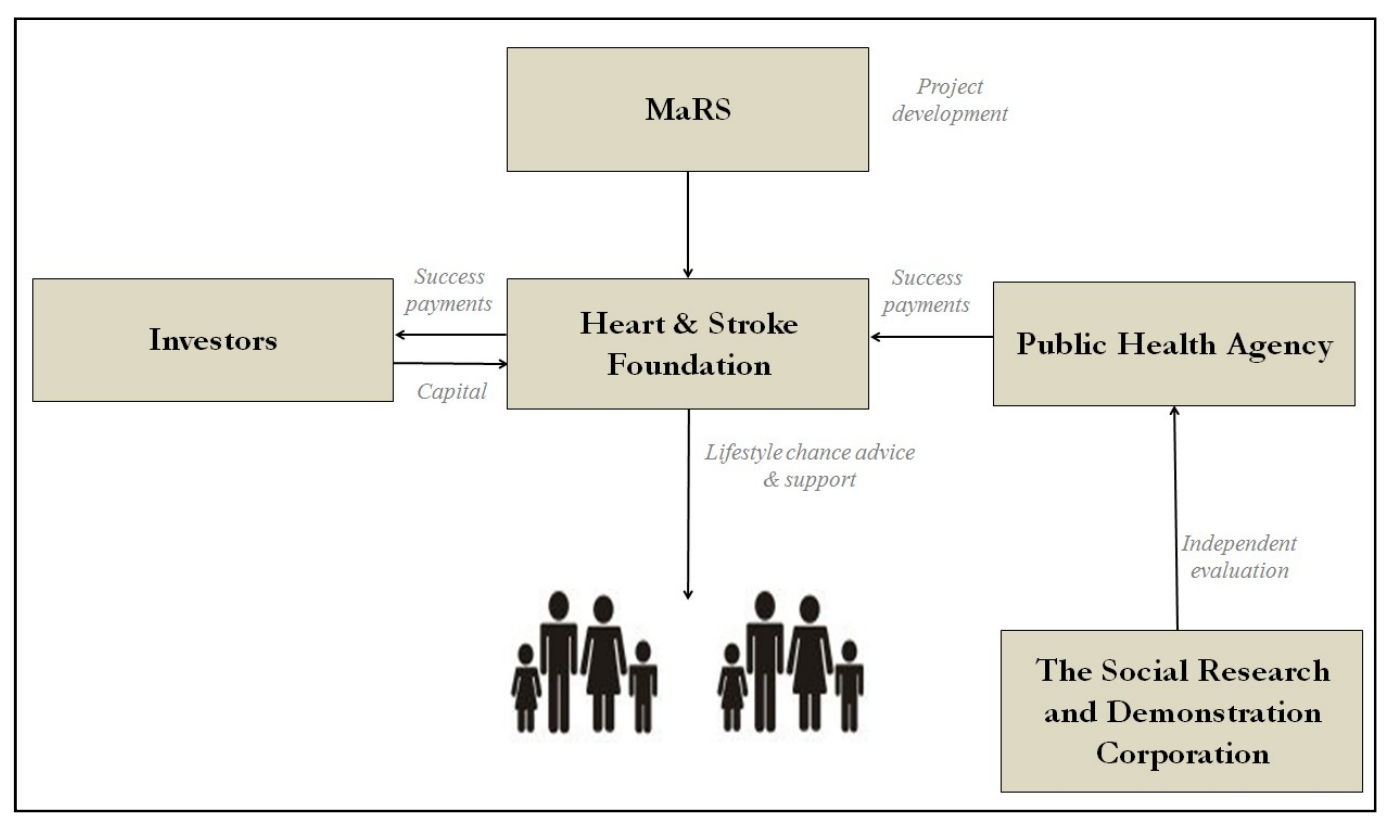

Figure 2. The H\&S operating model.

The investors provided $\$ 2.9$ million to fund the programs, with success in reducing blood pressure among the involved beneficiaries resulting in a return of up to $8.8 \%$ [60]. In particular, investors will receive a 6.7 percent return on investment if the project will meet the predefined targets and up to 8.8 percent if they exceed them [61].

The structure of the H\&S HIB is based on two main contracts. The first contract, between the Public Health Agency of Canada (PHAC) and the Heart and Stroke Foundation of Canada (HSF), is a contribution agreement conditioned on intake volume and blood pressure, and the second, between HSF and the investors, under the form of a loan agreement outlining payment schedules on intake volume and blood pressure [59] (Figure 3).

The Public Health Agency of Canada (PHAC) and the Heart and Stroke Foundation of Canada (HSF) decided to evaluate the effect of the program by comparing the results achieved with a historic population baseline rather than with a control group. As clarified by MaRS [59,60], in the H\&S HIB, the commissioner (PHAC) is not motivated by public savings and due to this, payments are not related to a mere saving object [60]. The project is based around two main metrics: the intake volume metric and the blood pressure metric. The first is calculated by considering the number of people who submit to a blood pressure reading and sign up for the program, while the second is based on the average change in blood pressure across all participants after six months [59]. 


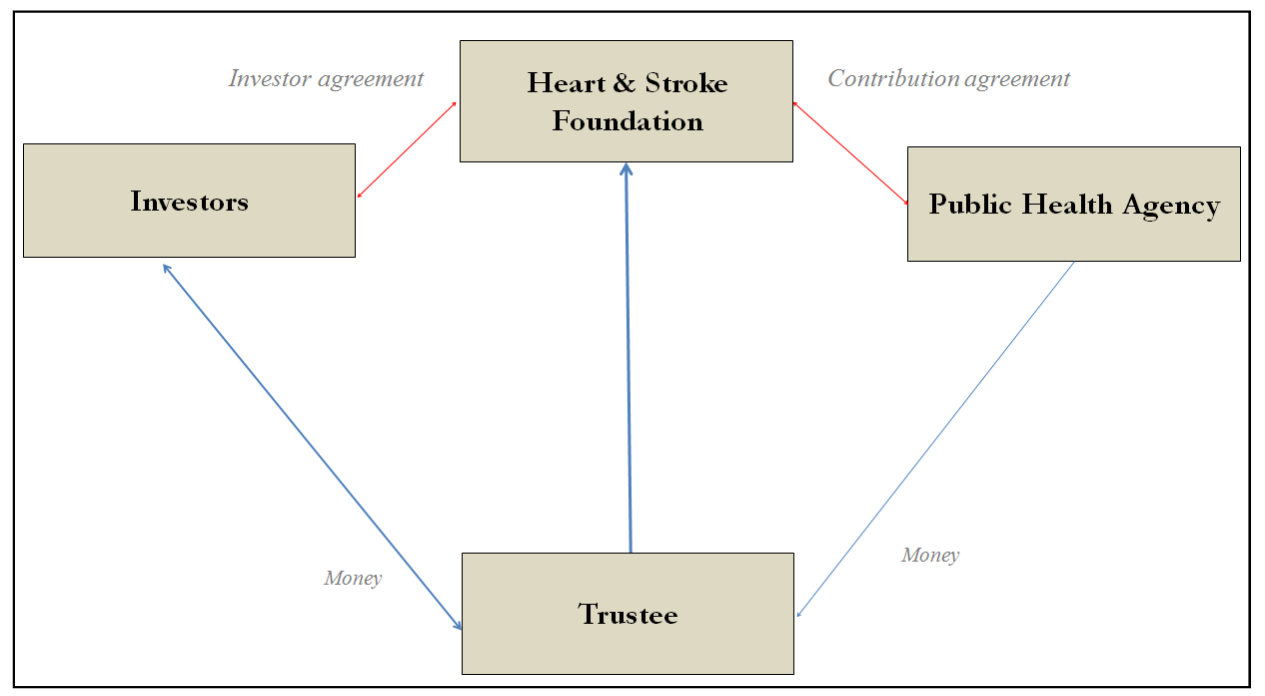

Figure 3. H\&S HIB contracting details. Source: Adapted from MaRS (2018).

\subsection{The Ways to Wellness HIB}

The Ways to Wellness HIB was launched in 2015 and is focused on people with long-term conditions that represent the most frequent users of British healthcare services. Ways to Wellness SIB is a social prescribing intervention targeting people aged 40-74 living in areas of high socio-economic deprivation with long term health conditions. The program provides support to patients in managing their long-term conditions by helping them identify meaningful health and wellness goals through personalized support. The success of the program is based on the improvement in patient wellbeing and reductions in hospital visits, admissions, and the length of hospital stays [62-64].

The HIB was commissioned by Newcastle Gateshead CCG (the CCG), which received 'top-up' payments to help cover some of the outcome payments from the Big Lottery Fund, Commissioning Better Outcomes (CBO) Fund, and the Cabinet Office's Social Outcomes Fund (SOF) [63]. A large number of different intermediaries/consultancies have been involved in this HIB such as:

- Social Finance, who provided the estimation of the costs and benefits of the program, and supported the development of the financial model and the outcome metrics;

- $\quad$ Rocket Science, who provided support in managing the procurement of the service providers;

- NHS North East Quality Observatory System (NEQOS), who analyzed local data on long term conditions and provided support in identifying promising areas for cost savings; and

- Vital Services North East, who developed the management information systems and the IT infra-structure [63].

Table 3 provides an overview of the main involved partners.

Table 3. Involved partners in the Ways to Wellness HIB.

\begin{tabular}{ll}
\hline Commissioner & Newcastle Gateshead CCG (the CCG) \\
\hline Outcome payers & $\begin{array}{l}\text { Newcastle Gateshead CCG (the CCG), Big Lottery Fund, Commissioning Better Outcomes } \\
\text { (CBO) Fund, and the Cabinet Office's Social Outcomes Fund (SOF) }\end{array}$ \\
\hline Service Provider & $\begin{array}{l}\text { Lead service provider: Ways to Wellness } \\
\text { Subcontractors: First Contact Clinical, Mental Health Concern, Healthworks Newcastle, } \\
\text { Changing Lives }\end{array}$ \\
\hline Investment manager & Bridges Fund Management \\
\hline Investors & Bridges Fund Management through its Social Impact Bond and Social Entrepreneurs Fund \\
\hline Intermediaries/consultancies & $\begin{array}{l}\text { Social Finance UK, Rocket Science, NHS North East Quality Observatory System (NEQOS), } \\
\text { Vital Services North East }\end{array}$ \\
\hline & Source: Our elaboration of publicly available information.
\end{tabular}


The deal was led through a special purpose vehicle (SPV) named Ways to Wellness Limited, which was established to operate as the prime contractor supervising the delivery of the program by the four local providers with a board that included members of Bridges Fund Management (BFM), Newcastle West CCG, and VONNE (Voluntary Organizations' Network North East). BFM have provided upfront finance to the SPV [10,65] (Figure 4).

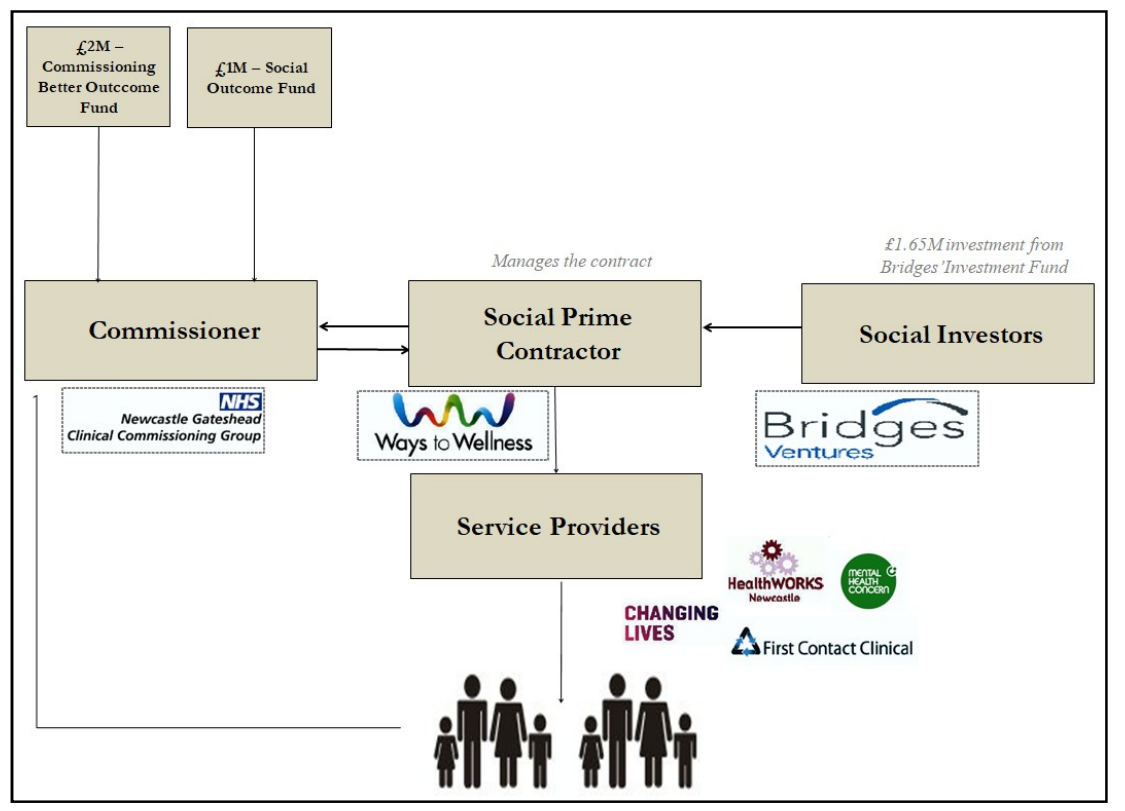

Figure 4. The Ways to Wellness contractual scheme. Source: Adapted from CBO [63,64].

Repayments to investors will be governed by the contract with the Newcastle Gateshead Clinical Commissioning Group and will be determined on the basis of long-term savings related to the reduction of hospital services. Public savings were estimated for CCG to be $£ 10.8 \mathrm{~m}$, while the estimated broader public service savings were $£ 13.6 \mathrm{~m}[10,64,65]$. The project is structured around two outcome measures:

- $\quad$ Outcome A: based on a change in wellbeing measured on the basis of a 'Wellbeing Star' at 6-month intervals. These outcomes are the main performance measures in the first two years of the project, with most of the funds coming from central government sources in the early years; and

- Outcome B: based on a cohort reduction in secondary care compared with a counterfactual group. Outcome B measurements are scheduled in the third year of the program from April 2018 and are to be funded from local commissioning funds $[10,65]$.

Overall, the total expected outcome payments made to Ways to Wellness in the first six years are $£ 8.2 \mathrm{~m}$. For Outcome A, payments are related to the Wellbeing Star indicators, with payments increasing incrementally up to $£ 500$ per beneficiary. The remaining payments are related to the reduction in secondary care costs (Outcome B), for which the Clinical Commissioning Group (CCG) will pay a maximum of $£ 330$ per annum in the case that the success targets are achieved [58].

From a financial point of view, Tan et al. [65] classified the Way to Wellness HIB as a fully at-risk investment without a no fixed coupon or a secured level of return.

\subsection{Mental Health and Employment Social Impact Bond}

The Mental Health and Employment Social Impact Bond (SIB) addresses the employment support needs of 2500 individuals living with severe mental health illness, based on having an employment advisor embedded in local mental health professional teams. The project was developed around the Mental Health and Employment Partnership (MHEP), a vehicle through which local commissioners of 
mental health supported employment services can procure a specialist intervention named "Individual Placement and Support" (IPS).

MHEP was established by Social Finance using the social investment partnership (SIP) model with an initial investment of $£ 400,000$ from Big Issue Invest, which retains $100 \%$ of the ownership [63,64].

MHEP supported the commissioning of three year IPS service contracts with three local public entities: the Staffordshire County Council (Staffordshire), London Borough of Haringey (Haringey), and Tower Hamlets Clinical Commissioning Group (Tower Hamlets) [66]. Under this arrangement, MHEP makes available a ready-to-use flexible contract that is able to provide different contractual arrangements according to each commissioner's needs [67]. Consequently, the deal is characterized by different contracting models at the local level (Figure 5). The direct costs of designing the SIB were $£ 150 \mathrm{k}$, which corresponded to the cost of the grant that Social Finance received from the CBO Fund [66].

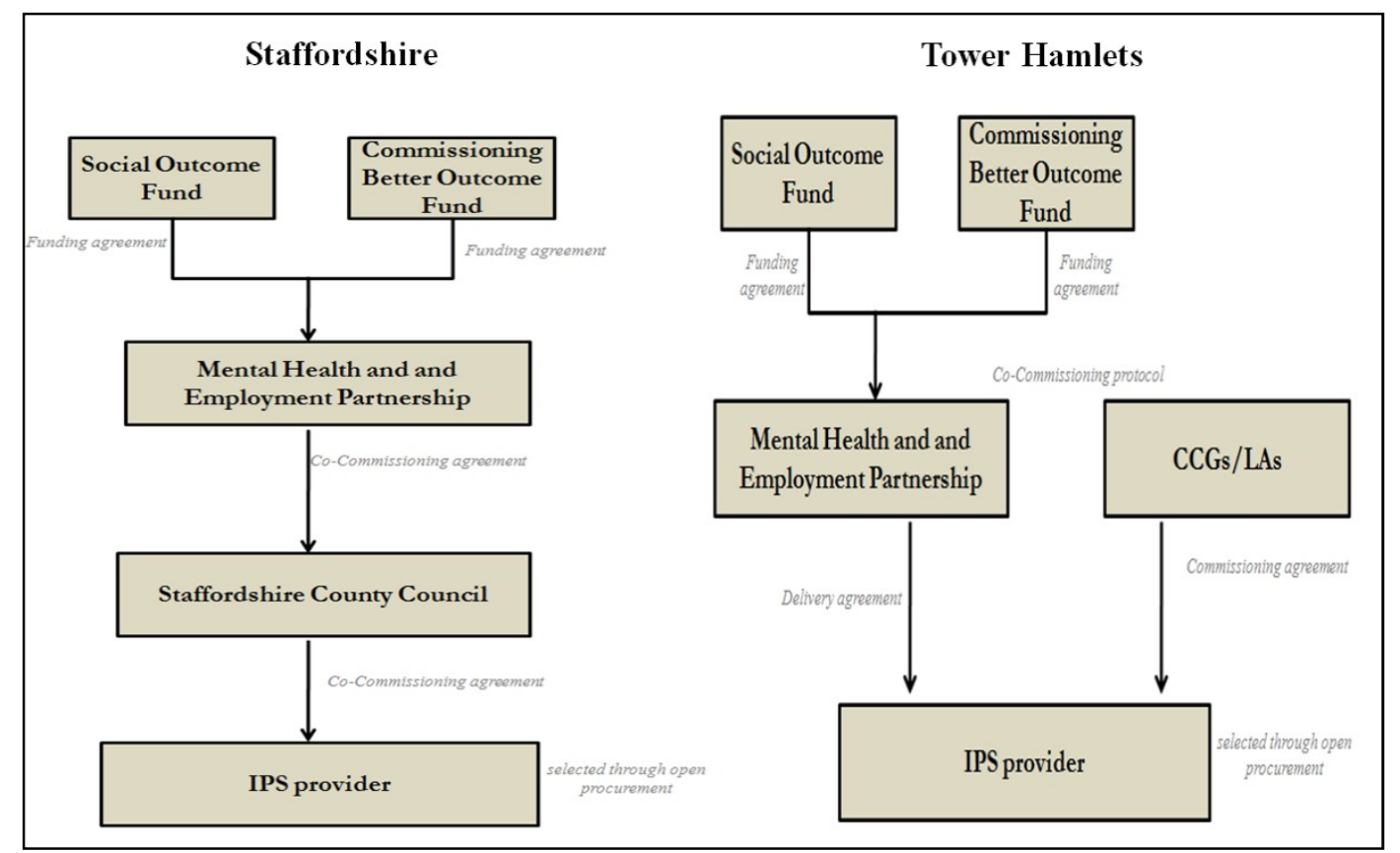

Figure 5. Tower Hamlets and Staffordshire: structure and agreements. Source: Our elaboration from MHEP [67].

The main partners involved are summarized in Table 4.

Table 4. Partners involved in the Mental Health and Employment HIB.

\begin{tabular}{ll}
\hline Commissioners & $\begin{array}{l}\text { Staffordshire County Council, London Borough of Haringey, Tower Hamlets Clinical } \\
\text { Commissioning Group, Commissioning Better Outcomes Fund, Social Outcomes Fund }\end{array}$ \\
\hline Intermediary & Social Finance (model development and contract management) \\
\hline Investor & Big Issue Invest \\
\hline & Source: Our elaboration on publicly available information.
\end{tabular}

The rationale for the Social Outcome Fund paying for the outcomes is that they reflect savings to central government, while the rationale for the Commissioning Better Outcomes Fund is related to the potential for social impact on the service users, for engaging with local providers, and for scaling, replication, and generating impactful learning [66].

Table 5 provides an overview of the outcome payment scheme. 
Table 5. The outcome payment scheme in the Mental Health and Employment HIB.

\begin{tabular}{|c|c|c|c|c|c|}
\hline & \multirow{2}{*}{$\begin{array}{l}\text { Successful Engagement } \\
\text { of Users }\end{array}$} & \multicolumn{2}{|c|}{ Job Entry Outcome } & \multicolumn{2}{|c|}{ Job Sustainment Outcome } \\
\hline & & (<16 Hours/Week) & (>16 Hours/Week) & (<16 Hours/Week) & (>16 Hours/Week) \\
\hline $\begin{array}{l}\text { Outcome } \\
\text { payment }\end{array}$ & $£ 790-£ 1000$ & $£ 700$ & $£ 1350$ & $£ 1400$ & $£ 1650$ \\
\hline $\begin{array}{l}\text { Payment } \\
\text { made by }\end{array}$ & $\begin{array}{c}\text { MHEP/Big Issue Invest (20\%) } \\
\text { Commissioner }(70 \%) \\
\text { Social Outcome } \\
\text { Fund/Commissioning Better } \\
\text { Outcomes Fund }(10 \%)\end{array}$ & $\begin{array}{l}\text { Social Outcome } \\
\text { Fund/Commissioning } \\
\text { Better Outcomes } \\
\text { Fund }(100 \%)\end{array}$ & $\begin{array}{c}\text { Social Outcome } \\
\text { Fund/Commissioning } \\
\text { Better Outcomes } \\
\text { Fund }(100 \%)\end{array}$ & $\begin{array}{c}\text { Social Outcome } \\
\text { Fund/Commissioning } \\
\text { Better Outcomes } \\
\text { Fund }(100 \%)\end{array}$ & $\begin{array}{l}\text { Social Outcome } \\
\text { Fund/Commissioning } \\
\text { Better Outcomes } \\
\text { Fund }(100 \%)\end{array}$ \\
\hline
\end{tabular}

\subsection{The Reconnections Social Impact Bond}

The Reconnections Social Impact Bond aims to reduce loneliness and isolation for 3000 people over the age of 50 in Worcestershire. The SIB was commissioned by the Worcestershire County Council (WCC) with three co-commissioners from Clinical Commissioning Groups. NESTA, an innovation foundation-based in the UK, is the main funder and Age UK Herefordshire and Worcestershire is the main service provider [68]. The development of the Reconnections Social Impact Bond will lead to savings of $£ 3$ million to the public purse over a 15 -year period, while the costs of development were around $£ 189,000$ [16]. The Reconnection deal is characterized by the presence of a principal commissioner (Worcestershire County Council) and three co-commissioners (Clinical Commissioning Groups, CCGs) [68]. Age UK H\&W were the prime contractor for the service and there were six subcontracted local service providers (of which Age UK H\&W was one) to carry out the intervention while Social Finance provided the operational support and outcomes monitoring for the SIB $[10,65]$. The main partners involved in the Reconnections SIB are summarized in Table 6.

Table 6. Partners involved in the Reconnection HIB.

\begin{tabular}{ll}
\hline \multirow{2}{*}{ Commissioners } & Worcestershire County Council \\
& Clinical Commissioning Groups (South Worcestershire CCG, Redditch and \\
& Bromsgrove CCG and Wyre Forest CCG) \\
\hline \multirow{3}{*}{ Service provider } & Lead service provider: Age UK Herefordshire and Worcestershire \\
& $\begin{array}{l}\text { Subcontracted service providers: Age UK Herefordshire and Worcestershire, } \\
\text { Age UK Malvern, Onside Advocacy, Rooftop, Simply Limitless, Worcester } \\
\text { Community Trust }\end{array}$ \\
\hline Intermediary & Social Finance \\
\hline Investor & Care and Wellbeing Fund Nesta Impact Investments Age UK \\
\hline & Source: our elaboration on publicly available information.
\end{tabular}

From a contractual perspective, the Reconnections SIB is managed by Reconnections Ltd. (the $\mathrm{SPV}$ ) owned by the investors (Nesta Impact Investments, the Care and Wellbeing Fund), and managed by Social Finance) and Age UK [68].

The contractual structure is summarized in Figure 6.

The maximum amount of outcome payments related to the Reconnections SIB is $£ 2.02$ million, which can be broken down as follows: $£ 697,000$ from the Social Outcome Fund; $£ 1.02$ million from the Commissioner; and $£ 303,000$ from the Commissioning Better Outcomes Fund.

The cost of developing the SIB was $£ 189,000$ including a $£ 90,000$ grant from the Department of Health to carry out the cost-benefit analysis of the project; $£ 64,000$ from the Development Grant from the Commissioning Better Outcomes Fund to help develop the project; and a £35,000 in-kind contribution from the WCC linked to staff time undertaken to further develop the SIB [68]. 


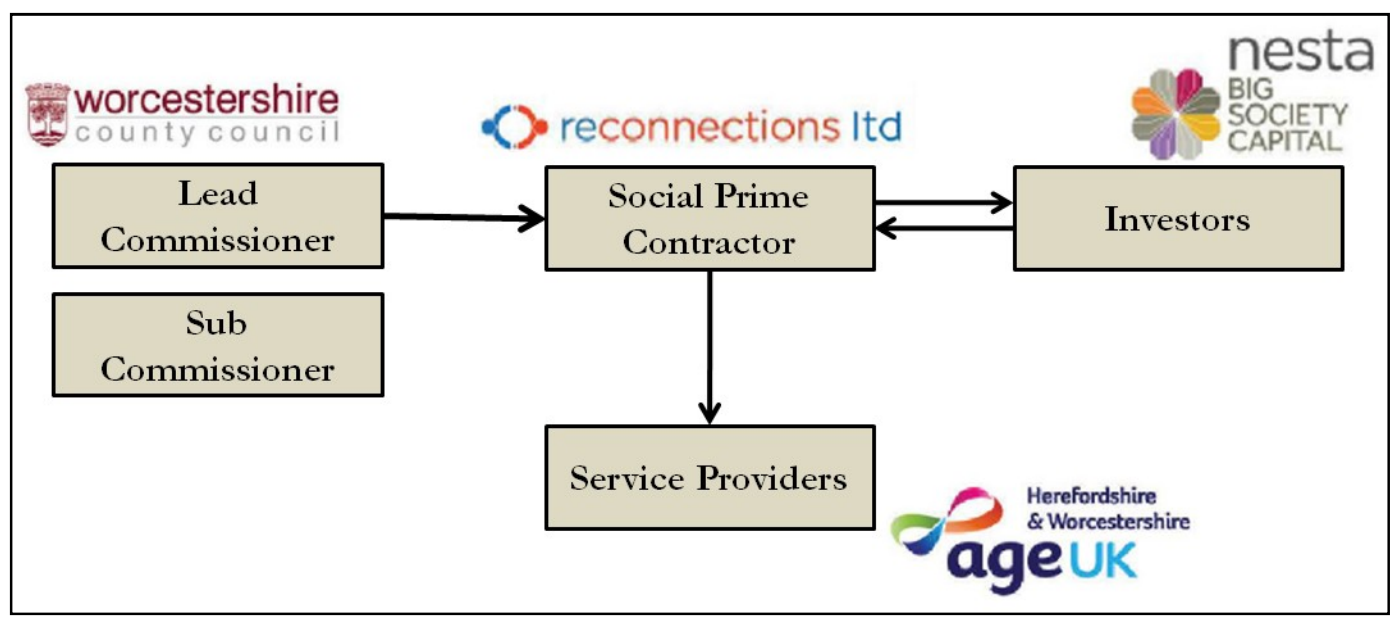

Figure 6. The contractual structure of the Reconnections SIB. Source: Adapted from CBO [68].

\section{Insights from Case Studies: Main Research Findings}

With regard to the possibility of driving welfare initiatives through SIBs by moving from an initial governmental policy, both Canada and the UK have gradually developed their legal frameworks in order to facilitate the proliferation of these kinds of instruments.

With regard to Canada, the H\&S HIB has been launched under a community prevention program by the Public Health Agency. The country's interest in SIBs is contained in Canada's 2012 Economic Action Plan, which called for greater exploration of the potential of SIBs $[6,69,70]$. In October 2013, the Minister for Employment and Social Development Canada announced Canada's first social finance pilot projects and several provincial governments have undertaken or are exploring social financing models such as Alberta's Social Innovation Fund, Ontario's development of social impact bond pilot projects, and Saskatchewan's appointment of a legislative secretary for social impact bonds [71-75]. At the federal level, the government first identified an interest in social finance in Budget 2011 and made further references to social finance in subsequent budgets, and in 2012 issued a "call for concepts" for social finance ideas, and has since initiated some tentative experiments with social finance approaches $[70,74]$.

With regard to the UK, between 2017 and 2018, five new HIBs were launched, with programs spanning end-of-life care (Your Life Line 24/7) and HIV prevention and treatment (launched by the Elton John AIDS Foundation) to learning disabilities ('Positive Behavioral Support' (PBS) in Bradford) and diabetes prevention (Healthier Devon). Since 2010, the United Kingdom has developed a strategy framework for social investing $[65,76,77]$ by developing and launching several market-building initiatives, such as an independent financial institution (Big Society Capital) that was established to develop and shape a sustainable social investment market. Since 2012, the Big Lottery Fund, which is a non-departmental public body responsible for distributing funds raised by the National Lottery for "good causes", and the Cabinet Office started working together to support the development of more innovative approaches to improve social outcomes by developing the Cabinet Office's Social Outcomes Fund and the Big Lottery Fund's Commissioning Better Outcomes with the joint mission to support the development of more SIBs [78]. An overview of the UK Government Outcomes Funds for the development of SIBs is provided in Table 7. 
Table 7. UK Government outcomes funds for SIBs.

\begin{tabular}{ll}
\hline \multicolumn{1}{c}{ Fund } & \multicolumn{1}{c}{ Description } \\
\hline $\begin{array}{l}\text { Social Outcomes Fund and } \\
\text { (Commissioning Better Outcomes Fund }\end{array}$ & $\begin{array}{l}\text { The Social Outcomes Fund ( } £ 20 \mathrm{~m}) \text { and Commissioning Better Outcomes } \\
(£ 40 \mathrm{~m}) \text { were established by the Cabinet Office and the Big Lottery Fund } \\
\text { with the aim to support the development of SIBs in policy areas by } \\
\text { providing support/funding in the development stage and by paying for } \\
\text { a part of the outcomes payments. Commissioning Better Outcomes was } \\
\text { been set up by the Big Lottery Fund. The Social Outcomes Fund is } \\
\text { a Government (Cabinet Office) funded initiative. }\end{array}$ \\
\hline $\begin{array}{l}\text { Life Chances Fund (Department for } \\
\text { Digital, Culture, Media and Sport) }\end{array}$ & $\begin{array}{l}\text { The Life Chances Fund provides support for locally commissioned SIBs } \\
\text { government to contribute to outcome payments for payments by results } \\
\text { (PbR) schemes which involve socially minded investors. The LCF will aim } \\
\text { for contributions of around 20 per cent of total outcomes payments, } \\
\text { with local commissioners paying for the majority of the } \\
\text { outcomes payments. }\end{array}$ \\
\hline $\begin{array}{l}\text { Youth Engagement Fund (Department } \\
\text { for Work and Pensions) }\end{array}$ & $\begin{array}{l}\text { The Youth Engagement Fund is a } £ 16 \text { million PbR fund that was } \\
\text { established by DWP and the Cabinet Office to help disadvantaged young } \\
\text { people aged 14 to } 17 \text { to participate and succeed in education or training. }\end{array}$ \\
\hline
\end{tabular}

Fair Chance Fund (Department for

Communities and Local Government and Cabinet Office)

The Rough Sleeping SIB Fund

(Department for Communities and Local Government)

\section{Innovation Fund (Department for Work} and Pensions)
The Fair Chance Fund is used to fund seven Social Impact Bonds (SIBs) focused on improving outcomes for young homeless people.

The fund aims to help long-term rough sleepers with complex needs over 3 years: 2016 to 2017, 2017 to 2018, and 2018 to 2019.

The Innovation Fund (IF) pilot was delivered between April 2012 and November 2015 to support young people aged 14 or over who were considered disadvantaged or at risk of disadvantage. The IF pilot was comprised of ten projects, which were commissioned in two rounds.

In the same vein, in 2013 the project "Trailblazers", which included nine projects across England, received seed funding from the government's Social Enterprise Investment Fund to evaluate and potentially develop SIB projects [76]. Table 8 provides an overview of the nine projects.

Table 8. "Trailblazers" projects.

\begin{tabular}{lll}
\hline \multicolumn{1}{c}{ Project } & \multicolumn{1}{c}{ Intervention Area } & \multicolumn{1}{c}{ Result } \\
\hline Sandwell and Birmingham & End of life services & Not commissioned. \\
\hline Cornwall & $\begin{array}{l}\text { Frail older people with LTCs at risk of } \\
\text { emergency admission }\end{array}$ & Not commissioned. \\
\hline East Lancashire & $\begin{array}{l}\text { Isolation, unemployment and poor } \\
\text { quality of life }\end{array}$ & $\begin{array}{l}\text { Not commissioned (the service has been } \\
\text { funded outside a PbR scheme). }\end{array}$ \\
\hline Manchester & $\begin{array}{l}\text { Nursing care for people with } \\
\text { neurological trauma }\end{array}$ & Not commissioned. \\
\hline Newcastle & Behavioral interventions for children & In progress. \\
\hline Shared Lives & $\begin{array}{l}\text { Better self-management of long-term } \\
\text { conditions through social prescribing }\end{array}$ & In progress. \\
\hline Thames Reach & $\begin{array}{l}\text { Alternative to care homes for people in } \\
\text { need for intensive support }\end{array}$ & $\begin{array}{l}\text { Two SIBs were signed and are under } \\
\text { development in Lambeth and } \\
\text { and Thurrock (from 2017). }\end{array}$ \\
\hline Worcester & $\begin{array}{l}\text { Personalized service pathway } \\
\text { for homeless }\end{array}$ & $\begin{array}{l}\text { In progress. } \\
\text { tailored support }\end{array}$ \\
\hline
\end{tabular}


The analysis of our cases allowed for the identification of three different contractual models. In the H\&S HIB, investor capital to HSF and outcome payments to investors flow through a trustee and the entire deal is arranged around two main contracts: the first, a contribution agreement between the PHAC and HSF, and the second, a loan agreement between HSF and the investors. In the Ways to Wellness and Reconnection HIBs, the deals are led through a special purpose vehicle (SPV) (owned by the investors, in the second case) while in the Mental Health and Employment HIB, the deal is arranged around the Mental Health and Employment Partnership (MHEP) by using a social investment partnership (SIP) model. The SIP model has led to the development of different local business models by promoting the possibility of replicating the same intervention scheme at different local levels and by promoting the collaboration between different public authorities. Table 9 provides an overview of the core aspects of our analysis.

Table 9. A comparison of the case studies.

\begin{tabular}{|c|c|c|c|c|}
\hline & H\&S HIB & Ways to Wellness HIB & $\begin{array}{l}\text { Mental Health \& } \\
\text { Employment HIB }\end{array}$ & Reconnection HIB \\
\hline Contractual model & $\begin{array}{l}\text { Two different contracts and } \\
\text { presence of a trustee }\end{array}$ & Special Purpose Vehicle (SPV) & $\begin{array}{l}\text { (a) Social Investment } \\
\text { Partnership (SIP) model, } \\
\text { (b) Different local } \\
\text { business models. }\end{array}$ & $\begin{array}{l}\text { Special purpose vehicle (SPV) } \\
\text { owned by the investors. }\end{array}$ \\
\hline $\begin{array}{l}\text { Project } \\
\text { commissioner }\end{array}$ & Public Health Agency & $\begin{array}{l}\text { The HIB has been } \\
\text { commissioned by Newcastle } \\
\text { Gateshead CCG (the CCG) that } \\
\text { received from Big Lottery Fund, } \\
\text { Commissioning Better } \\
\text { Outcomes (CBO) Fund and the } \\
\text { Cabinet Office's Social } \\
\text { Outcomes Fund (SOF) 'top-up' } \\
\text { payments to help cover some of } \\
\text { the outcome payments. }\end{array}$ & $\begin{array}{l}\text { Different local public } \\
\text { authorities. }\end{array}$ & $\begin{array}{l}\text { The Reconnections deal is } \\
\text { characterized by the presence of } \\
\text { a primary commissioner } \\
\text { (Worcestershire County Council) } \\
\text { and three co-commissioners } \\
\text { (Clinical Commissioning Groups, } \\
\text { CCGs) that help to ensure } \\
\text { a joined up and } \\
\text { multiagency approach. }\end{array}$ \\
\hline $\begin{array}{l}\text { Collaboration } \\
\text { between different } \\
\text { public authorities }\end{array}$ & $\begin{array}{l}\text { The project was developed at the } \\
\text { federal level around the } \\
\text { collaboration between the Public } \\
\text { Health Agency and the Heart and } \\
\text { Stroke Foundation. }\end{array}$ & $\begin{array}{l}\text { The deal is developed around } \\
\text { the collaboration between } \\
\text { a local authority and the } \\
\text { outcome funds. }\end{array}$ & $\begin{array}{l}\text { The deal is developed } \\
\text { around the collaboration } \\
\text { between local and central } \\
\text { authorities. }\end{array}$ & $\begin{array}{l}\text { The deal is developed around the } \\
\text { collaboration between a local } \\
\text { authority with three } \\
\text { co-commissioners. }\end{array}$ \\
\hline $\begin{array}{l}\text { Predefined level } \\
\text { of public savings }\end{array}$ & $\begin{array}{l}\text { (a) The deal is not related to } \\
\text { a predefined level of public } \\
\text { savings. }\end{array}$ & $\begin{array}{l}\text { (a) The deal is related to } \\
\text { a predefined level of } \\
\text { public savings. }\end{array}$ & $\begin{array}{l}\text { (a) The deal is related to } \\
\text { a predefined level of } \\
\text { public savings. }\end{array}$ & $\begin{array}{l}\text { (a) The deal is related to } \\
\text { a predefined level of } \\
\text { public savings. }\end{array}$ \\
\hline Financial advisor & $\begin{array}{l}\text { MaRS (model development and } \\
\text { contract management). }\end{array}$ & $\begin{array}{l}\text { Social Finance UK (model } \\
\text { development and contract } \\
\text { management). }\end{array}$ & $\begin{array}{l}\text { Social Finance UK (model } \\
\text { development and } \\
\text { contract management). }\end{array}$ & $\begin{array}{l}\text { Social Finance UK (model } \\
\text { development and contract } \\
\text { management). }\end{array}$ \\
\hline Investors & $\begin{array}{l}\text { Businesses, charitable foundations, } \\
\text { and wealthy individuals. }\end{array}$ & Bridges Fund Management. & Big Issue Invest. & $\begin{array}{l}\text { Care and Wellbeing Fund; Nesta } \\
\text { Impact Investments; Age UK. }\end{array}$ \\
\hline Rate of return & $\begin{array}{l}\text { - } 6.7 \text { percent return on } \\
\text { investment if the project } \\
\text { meets its targets; } \\
\text { > } 8.8 \text { percent profit if it } \\
\text { exceeds the target. }\end{array}$ & $\begin{array}{l}\text { if the project meets its } \\
\text { targets, the estimated } \\
\text { money multiple over } \\
\text { seven years will be } \\
\text { c. } 1.38 \text { times the } \\
\text { initial investment; } \\
\text { if the outcomes achieved } \\
\text { are lower than the base } \\
\text { case, the multiple could } \\
\text { be much lower and } \\
\text { conceivably all } \\
\text { investment could be lost. }\end{array}$ & $\begin{array}{l}\text { Data not } \\
\text { provided/unconfirmed. }\end{array}$ & Data not provided/unconfirmed. \\
\hline
\end{tabular}

Source: Our elaboration from publicly available information.

From Table 9, it is interesting to note that all of the analyzed cases were built around a series of collaborations between different kind of partners including foundations, outcome funds, and public authorities at both the central and local level.

\section{Enabling Factors}

Currently, no large SIBs have been commissioned and are still at a relatively small scale in terms of lives touched (beneficiaries) and capital $[79,80]$.

SIBs have also been the object of strong criticism due, for example, to a lack of evidence regarding their effectiveness [80] and for the "win-win narrative" through which they have been promoted in many countries [21]. Skepticism also lies in the absence of compelling supporting evidence, 
to the presence of high transaction costs $[20,80]$, or to ethical issues such as the "financialization" or "marketization" of social policies $[28,61,80,81]$.

On the other hand, academics and practitioners have widely recognized some key aspects that should be considered for the development of SIBs. In this vein, for example, Giantris and Pinakiewicz [82] (p. 35) clarified that the first step for the implementation of a SIB financing scheme was to understand the risk trade-offs that underpin it and in particular, the potential for measurable social impact and the possibility of identifying and capturing the economic value of social impact; the financial and reputational risk (and return) for each of the involved parties; the transaction, execution, governance, and due diligence costs; the cost of capital to the commissioner and service provider(s); the legal framework and the changes in procurement and contracting systems; and the potential for replication and scaling.

The analysis of our case studies led us to catch a series of enabling factors that could potentially promote the development of both SIBs and HIBs and their scalability/replicability.

\subsection{Building the Market Space: The Role of Governmental Policies}

The experiences of Canada and the UK demonstrate that the vivacity of the SIB marketconsidering that these two countries cover $42 \%$ of the global market-is strongly influenced by the development of policies that recognize the importance of social finance. In this sense, since 2010, several market-building initiatives have been launched including an independent financial institution (Big Society Capital), and since 2012, the Big Lottery Fund and the Cabinet Office have started working together to support the development of more innovative approaches to improving social outcomes by developing the Cabinet Office's Social Outcomes Fund and the Big Lottery Fund's Commissioning Better Outcomes. In the same vein, since 2012, Canada has developed an "Economic Action Plan", which calls for greater exploration of the potential of SIBs. All of these initiatives summarize the interest in the development of innovative funding schemes starting from the central level, followed by the local authorities (e.g., the Government of Alberta).

Moreover, both these countries have social finance intermediaries and social impact/outcomes funds that help the improvement of single deals. The role of "financial infrastructure" is also highlighted by Albertson et al. [76], who clarified how social finance intermediaries were often able to provide technical assistance in the project development and implementation phases. At the same time, and as emerged from our cases, social outcome funds represent the primary funders of SIBs (especially in the UK), thus overcoming the need to find other financial resources.

\subsection{Improving Scalability and Replicability through Robust Contractual Schemes}

The fact that SIBs are not a bond or a debt instrument in the traditional sense has been widely clarified in the academic literature $[13,16,83]$. Under a financial point of view, a SIB contract implies a series of social/economic futures contracts between the involved parties [79]. The contractual scheme is at the center of the partnership and defines the relationship between the parties, their respective rights and responsibilities, allocates risk, and provides mechanisms for dealing with change. A well-defined contractual scheme should create certainty where possible, and bounded flexibility where needed, thereby retaining clarity and limiting uncertainty for both parties. The possibility of testing and developing new forms of contractual schemes that best fit the needs of both public and private parties could improve the development of the SIB/HIB market. At the same time, contractual schemes set the boundaries under which public sector and private entities cooperate and share risks and profits to provide the predefined services.

SIBs require the careful analysis of risks by the private and public sector. From this perspective, SIBs consist of the allocation of risks among parties by means of the proper design of contract agreements, consequently, the allocation of risks cannot be separated from an analysis of the contracting terms between the parties. 
Simultaneously, risk transfer from the government to the private sector is crucial if SIB projects are to be cost-effective. For these reasons, if contracts are the basis upon which risks are allocated, then risk transfer is also a function of the forms of contracts. From these perspectives, standardization and modularity represent the two main factors that could lead the development of the SIB approach for welfare service provision by stimulating the interests of private counterparties.

In SIB contracts, the principal and agent could potentially have conflicting interests regarding the quality of service that should be achieved and the costs that should be incurred. Moreover, given the complexity of such contracts, audits and controls can be costly and very difficult to perform. This context makes more difficult to rely on a sole ex-ante competition to ensure that the ex-ante contracting on and the ex post delivery of service will be optimal. The competition for complex projects such as SIBs could be insufficient, with the potential effect that ex ante competition fails to guarantee the optimal value for money, especially when the contract is characterized by significant complexity and strong uncertainty. For these reasons, the question of the legislative environment represents one of the most important aspects that need to be developed. In this sense, the international experiences reveal that SIBs are usually developed by using the recurrent model "with SPV" that has led to the transfer of financial risks to a new venture created ad hoc for the development of the project. Moreover, the Canadian experience shows that relationships with the involved parties can be further regulated by using only two different contractual models: an investor agreement and a contribution agreement.

The question of aligned interests could be further analyzed as viewed by the UK experiences for two main reasons. First of all, HIBs, and in particular the cases of Tower Hamlets and Staffordshire, can be developed by using the same overall arrangements, but by making several adjustments at the local level. This implies that both the central and the local government work together for the implementation of the project and that a big deal developed and projected at the central level can become scalable at several levels. At the same time, this kind of structure involves parties that have, at different levels, the same interests. Second, from the UK experience, it is possible to note that all the involved parties, considering for example the MHEP case, have a sort of aligned interest in the success of the program including investors that in some cases are represented by social investment funds. The fact that in the analyzed cases where retail investors were not involved, can be intended as an opportunity to avoid the problems of aligned interest at least in this market development phase. In considering the role of robust contractual schemes, it is interesting to underline that in line with Edmiston and Nicholls [7] and Sinclair et al. [80], our cases revealed that in many cases, funders and intermediaries were heavily involved in the design of the initiatives they chose to finance. This seems to confirm the idea of La Torre et al. [18], who highlighted the role of SIBs as a "cross-sector partnership for sustainability" by stressing the concept that a fully collaborative partnership between all the involved parties may reduce the risk of failure.

\subsection{Institutional Variables and the Role of Partnerships for Sustainability}

A mix of exogenous conditions, i.e., severe public budget constraints and the emerging attitude of public authorities toward the provision of public services under the core idea that the mix of quality and efficiency is made possible by the involvement of the private sector in intervention areas traditionally confined to public budget spending, can be considered as replicability and scalability ingredients.

By the term "institutional variables", we refer to aspects such as the interests of public authorities at different governmental levels (local, regional, central) and their collaboration toward general objectives (for example, in the case of MHEP), the presence of an attitude toward efficiency and effectiveness in the provision of services, the attention toward themes such as the sustainability of public finance and accountability. The relationship between institutional variables and the development of SIBs is important for governments because if the public authorities have the right attitude toward them, arguably more SIBs would be developed in that country. However, the relationship is also important for the private parties as only when a good level of institutional interest toward the development of these particular financial schemes is present in a country will they arguably be inclined to offer their 
services and financing to such partnerships. The main implication of the institutional attention toward SIBs can be confirmed by the flourishing of initiatives aimed at promoting a social finance ecosystem (including financial intermediaries and outcome funds).

Governments, given their strict budget constraints, have significantly reduced the overall welfare expenditure. Under this perspective, SIBs could potentially increase the efficiency and effectiveness of the public sector in order to transfer, ceteris paribus, more risk to private parties and by reducing future avoidable costs and inefficiency.

\subsection{Dampening the Role of Evaluation and Public Savings}

As clarified by Cooper et al. [79], SIBs rely on a series of accounting aspects including budgets, future cashflows, discounting, performance measurement, and auditing by representing a potentially powerful and problematic use of accounting to enact government policy. Academic literature has widely recognized the general lack of successful evaluation practices by noting the importance of the identification of high-quality approaches for the development of the SIB market. The question of evaluation can be analyzed from many perspectives. First of all, if we consider the public sector side, the question of evaluation can be analyzed under the lens of "How much could I save by improving a social impact bond compared to a traditional procurement scheme?". In this sense, the question of evaluation can be reduced to the type of tools that can currently be used in the public sector including cost-benefit analysis and value for money methodologies. Previous works have suggested that SIBs are improved only by considering social issues and programs where it is possible to have measurable and achievable results (outcomes).

However, based on the Canadian experience, it is interesting to note that the core idea of the H\&S SIB is to emancipate outcome payments from public savings with the aim to make the contractual structure more flexible. From a public perspective, the idea to develop a HIB project without building outcome metrics around the boundaries of cost saving could be potentially justified under the aims of preventing a predefined or emerging health problem by considering a reduction in future costs for hospitalization and that an increased overall level of wellbeing represents a superior approach to health protection.

\section{Conclusions}

Economic shocks pose severe threats to healthcare systems by heightening fiscal pressure and stretching government resources while at the same time people rely more heavily on publicly financed health services. Essentially, the crisis has given substance to an old and often hypothetical debate about the sustainability of welfare systems, and, in particular, of health expenditure.

To bridge their huge funding gaps, welfare systems and governments across the world are increasingly searching for alternative financial schemes in line with the growing needs of the sustainability of public expenditure. Since 2010, 25 countries have developed welfare projects by using SIBs as a new and emerging social finance instrument that supports public sector initiatives by sharing the project risks with the private sector. SIBs have been seen as one instrument for overcoming certain barriers to scale as they combine the competencies, experiences, and financial resources of different actors to address difficult and pressing social issues. However, aspects such as risk, governance, information asymmetries, and misaligned interests between the involved parties have been underlined by the academic literature. However, the question that has emerged is whether it is right to consider only the problem of transaction costs, or alternatively, can transaction costs be mitigated by factors such as the level of social innovation achieved, the quality of the service provided, and the possibility of transferring the financial and reputational risks to the private sector. Currently, the feasibility of improving SIBs is constrained by issues of replicability across scale, sustainability over time, and inadequate market linkages. The development of a SIB market requires the creation of an enabling environment built around a series of ingredients. Our study provides a preliminary theorization of the main enabling factors that could potentially contribute to the development of SIBs 
as sustainable welfare instruments. Comparisons across the four cases were made to determine where similarities and differences existed and to identify several enabling factors. In particular, the four case studies made it apparent that there was (1) the possibility of driving welfare initiatives through SIBs by moving from an initial governmental policy; and (2) the possibility that particular contractual schemes could improve the scalability and replicability of SIBs. The use of scalable and replicable frameworks could potentially facilitate the implementation of SIB projects and therefore increase the likelihood of achieving value for money for the public sector. Future research directions could expand our understanding of the enabling factors by building a library of standard SIB types with groupings of type specific terms, conditions, protocols, and lessons learned. At the same time, further studies could try to develop a dashboard that is useful for the evaluation of the appropriateness of the SIB as well as try to analyze all of the contractual models detected though our analysis under the lens of the risks detected by all of the involved stakeholders and how they are managed under a principal-agent perspective.

Author Contributions: R.C. conceived, designed and conducted the research; R.D.L. supervised the research and gave valuable advice.

Funding: This research received no external funding.

Acknowledgments: The authors would like to express sincere gratitude for the valuable comments and suggestions received by the anonymous referees of Sustainability.

Conflicts of Interest: The authors declare no conflict of interest.

\section{References}

1. European Commission. Towards Social Investment for Growth and Cohesion-Including Implementing the European Social Fund 2014-2020; European Commission: Brussels, Belgium, 2013.

2. Karanikolos, M.; Mladovsky, P.; Cylus, J.; Thomson, S.; Basu, S.; Stuckler, D.; MacKenbach, J.P.; McKee, M. Financial crisis, austerity, and health in Europe. Lancet 2013, 381, 1323-1331. [CrossRef]

3. Sinclair, S.; McHugh, N.; Huckfield, L.; Roy, M.; Donaldson, C. Social Impact Bonds: Shifting the Boundaries of Citizenship. Soc. Policy Rev. 2014, 26, 119-136.

4. Thomson, S.; Figueras, J.; Evetovits, T.; Jowett, M.; Mladovsky, P.; Maresso, A.; Cylus, J.; Karanikolos, M.; Kluge, H. Economic Crisis, Health Systems and Health in Europe: Impact and Implications for Policy; World Health Organization, Regional Office for Europe: Geneva, Switzerland, 2015.

5. Berndt, C.; Wirth, M. Market, metrics, morals: The Social Impact Bond as an emerging social policy instrument. Geoforum 2018, 90, 27-35. [CrossRef]

6. Katz, A.S.; Brisbois, B.; Zerger, S.; Hwang, S.W. Social Impact Bonds as a Funding Method for Health and Social Programs: Potential Areas of Concern. Am. J. Public Health 2018, 108, 210-215. [CrossRef]

7. Edmiston, D.; Nicholls, A. Social Impact Bonds: The Role of Private Capital in Outcome-Based Commissioning. J. Soc. Policy 2017, 47, 57-76. [CrossRef]

8. Warner, M.E. Private finance for public goods: Social impact bonds. J. Econ. Policy Reform 2013, 16, 303-319. [CrossRef]

9. Del Giudice, A.; Migliavacca, M. Social Impact Bonds and Institutional Investors: An Empirical Analysis of a Complicated Relationship. Nonprofit Volunt. Sect. Q. 2019, 48, 50-70. [CrossRef]

10. Fraser, A.; Tan, S.; Lagarde, M.; Mays, N. Narratives of Promise, Narratives of Caution: A Review of the Literature on Social Impact Bonds. Soc. Policy Adm. 2016, 52, 4-28. [CrossRef]

11. Fox, C.; Albertson, K. Is payment by results the most efficient way to address the challenges faced by the criminal justice sector? Probat. J. 2012, 59, 355-373. [CrossRef]

12. Dowling, E. In the wake of austerity: Social impact bonds and the financialisation of the welfare state in Britain. New Political Econ. 2017, 22, 294-310. [CrossRef]

13. Clifford, J.; Jung, T. Social Impact Bonds: Exploring and Understanding an Emerging Funding Approach. In Routledge Handbook of Social and Sustainable Finance; Lehner, O., Ed.; Routledge: London, UK, 2016; pp. 161-176. 
14. Social Finance. SIB Database. Available online: https://sibdatabase.socialfinance.org.uk/ (accessed on 25 April 2019).

15. Rowe, R.; Stephenson, N. Speculating on health: Public health meets finance in 'health impact bonds'. Sociol. Health Illn. 2016, 38, 1203-1216. [CrossRef] [PubMed]

16. Carè, R.; Ferraro, G. Funding Innovative Healthcare Programs Through Social Impact Bonds: Issues and Challenges. China-USA Bus. Rev. 2019, 18, 1-15.

17. Quaglio, G.; Karapiperis, T.; Van Woensel, L.; Arnold, E.; McDaid, D. Austerity and health in Europe. Health Policy 2013, 113, 13-19. [CrossRef]

18. La Torre, M.; Trotta, A.; Chiappini, H.; Rizzello, A. Business Models for Sustainable Finance: The Case Study of Social Impact Bonds. Sustainability 2019, 11, 1887. [CrossRef]

19. So, I.; Jagelewski, A. Social Impact Bond: Technical Guide for Service Providers. Available online: https://learn.marsdd.com/wp-content/uploads/2013/11/MAR-SIB6939_Social-Impact-Bond-TechnicalGuide-for-Service-Providers_FINAL-ELECTRONIC1.pdf (accessed on 20 May 2019).

20. Morley, J. The ethical status of social impact bonds. J. Econ. Policy Reform 2019, 1-17. [CrossRef]

21. Fitzgerald, C.; Carter, E.; Dixon, R.; Airoldi, M. Walking the contractual tightrope: A transaction cost economics perspective on social impact bonds. Public Money Manag. 2019, 1-10. [CrossRef]

22. Social Finance UK. Social Impact Bond. The Early Years. Available online: https://www.socialfinance.org.uk/ sites/default/files/publications/sibs-early-years_social_finance_2016_final.pdf (accessed on 25 April 2019).

23. Giacomantonio, C. Grant-Maximizing but not Money-Making: A Simple Decision-Tree Analysis for Social Impact Bonds. J. Soc. Entrep. 2017, 8, 1-20. [CrossRef]

24. Maier, F.; Barbetta, G.P.; Godina, F. Paradoxes of social impact bonds. Soc. Policy Adm. 2018, 52, $1332-1353$. [CrossRef]

25. Maier, F.; Meyer, M. Social Impact Bonds and the Perils of Aligned Interests. Adm. Sci. 2017, 7, 24. [CrossRef]

26. Stid, D. Pay for success is not a panacea. Community Dev. Invest. Rev. 2013, 9, 13-18.

27. Azemati, H.; Belinsky, M.; Gillette, R.; Liebman, J.; Sellman, A.; Wyse, A. Social Impact Bonds: Lessons learned so far. Community Dev. Invest. Rev. 2013, 9, 23-34.

28. Giacomantonio, C. Setting realistic expectations: The narrow use-case for Social Impact Bonds. J. Community Saf. Well-Being 2018, 3, 93-95.

29. Pandey, S.; Cordes, J.J.; Pandey, S.K.; Winfrey, W.F. Use of social impact bonds to address social problems: Understanding contractual risks and transaction costs. Nonprofit Manag. Leadersh. 2018, 28, 511-528. [CrossRef]

30. Spiller, P.T. An Institutional Theory of Public Contracts: Regulatory Implications (No. w14152); National Bureau of Economic Research: Cambridge, MA, USA, 2008.

31. Spiller, P.T. A Tribute to Oliver Williamson: Regulation: A Transaction Cost Perspective. Calif. Manag. 2010, 52, 147-158. [CrossRef]

32. McHugh, N.; Sinclair, S.; Roy, M.; Huckfield, L.; Donaldson, C. Social impact bonds: A wolf in sheep's clothing? J. Poverty Soc. Justice 2013, 21, 247-257. [CrossRef]

33. Brandstetter, L.; Lehner, O.M. Opening the Market for Impact Investments: The Need for Adapted Portfolio Tools. Entrep. J. 2015, 5, 87-107. [CrossRef]

34. Flynn, J.; Young, J.; Barnett, C. Impact Investments: A literature Review; Centre for Development Impact: Brighton, UK, 2015. Available online: https:/opendocs.ids.ac.uk/opendocs/ds2/stream/?\#/documents/29293/ page/1 (accessed on 25 April 2019).

35. Wilson, K.E.; Silva, F.; Ricardson, D. Social Impact Investment: Building the Evidence Base. Organisation for Economic Co-Operation and Development. Available online: http://papers.ssrn.com/sol3/papers.cfm? abstract_id=2562082 (accessed on 25 April 2019).

36. Glynn, J.J.; Murphy, M.P. Public management: Failing accountabilities and failing performance review. Int. J. Public Sect. Manag. 1996, 9, 125-137. [CrossRef]

37. Siemiatycki, M.; Farooqi, N. Value for money and risk in public-private partnerships: Evaluating the evidence. J. Am. Plan. Assoc. 2012, 78, 286-299. [CrossRef]

38. Grimsey, D.; Lewis, M.K. Are public private partnerships value for money? Evaluating alternative approaches and comparing academic and practitioner views. Account. Forum 2005, 29, 345-378. [CrossRef]

39. Carè, R. Social Impact Bond: Beyond Financial Innovation. In Sustainable Financial Innovation; Wendt, K., Ed.; Taylor \& Francis: London, UK, 2018. 
40. Visconti, R.M. Multidimensional principal-agent value for money in healthcare project financing. Public Money Manag. 2014, 34, 259-264. [CrossRef]

41. Center for Disease and Control Prevention (CDC). Pay for Success: How-to Guide for Local Government Focused on Lead-Safe Homes. 2017. Available online: https://www.cdc.gov/nceh/lead/docs/pay_for_success_ guide.pdf (accessed on 25 April 2019).

42. Schinckus, C. The valuation of social impact bonds: An introductory perspective with the Peterborough SIB. Int. Bus. Financ. 2018, 45, 1-6. [CrossRef]

43. Eisenhardt, K.M. Building Theories from Case Study Research. Acad. Manag. 1989, 14, 532-550.

44. Baxter, P.; Jack, S. Qualitative case study methodology: Study design and implementation for novice researchers. Qual. Rep. 2008, 13, 544-559.

45. Dubois, A.; Gadde, L.-E. Systematic combining: An abductive approach to case research. J. Bus. 2002, 55, 553-560. [CrossRef]

46. Charmaz, K. Reconstructing grounded theory. In The Sage Handbook of Social Research Methods; SAGE Publications, Inc.: Thousand Oaks, CA, USA, 2008; pp. 461-478.

47. Glaser, B.; Strauss, A. The Discovery of Grounded Theory; Aldine Publishing Company: Hawthorne, NY, USA, 1967.

48. Dooley, L.M. Case Study Research and Theory Building. Adv. Dev. Hum. Resour. 2002, 4, 335-354. [CrossRef]

49. Lynham, S.A. Theory building in the human resource development profession. Hum. Dev. Q. 2000, 11, 159-178. [CrossRef]

50. Yin, R.K. Case Study Research: Design and Methods, 5th ed.; SAGE Publications, Inc.: Thousand Oaks, CA, USA, 2013.

51. Meredith, J. Building operations management theory through case and field research. J. Oper. Manag. 1998, 16, 441-454. [CrossRef]

52. Yin, R.K. Case Study Research: Design and Methods; SAGE Publications, Inc.: Thousand Oaks, CA, USA, 1994.

53. Patton, M.Q. Qualitative Research and Evaluation Methods, 3rd ed.; SAGE Publications, Inc.: Thousand Oaks, CA, USA, 2002.

54. Wang, F.; Wang, J.-D.; Huang, Y.-X. Health expenditures spent for prevention, economic performance, and social welfare. Health Econ. Rev. 2016, 6, 447. [CrossRef]

55. Strauss, A.; Corbin, J. Basics of Qualitative Research: Grounded Theory Procedures and Techniques; SAGE: Thousand Oaks, CA, USA, 1990.

56. Nag, R.; Gioia, D.A. From Common to Uncommon Knowledge: Foundations of Firm-Specific Use of Knowledge as a Resource. Acad. Manag. J. 2012, 55, 421-457. [CrossRef]

57. Wise, A. A Health Outcomes Fund for Canada. How Paying for Outcomes Could Improve Health and Deliver Better Value for Money. MaRS Centre for Impact Investing. Available online: https://www.marsdd. com/wp-content/uploads/2017/02/A-Health-Outcomes-Fund-for-Canada.pdf (accessed on 25 April 2019).

58. Rizzello, A.; Caridà, R.; Trotta, A.; Ferraro, G.; Carè, R. The Use of Payment by Results in Healthcare: A Review and Proposal. In Social Impact Investing Beyond the SIB; Palgrave Macmillan: Cham, Switzerland, 2018; pp. 69-113.

59. MaRS. Pionering Pay-for-Success in Canada. A New Way to Pay for Social Progress. Available online: https://www.marsdd.com/wp-content/uploads/2016/10/MaRS-Pioneering-Pay-For-Success-InCanada-Oct2016.pdf (accessed on 25 April 2019).

60. MaRS. Impact Report. Available online: https://www.marsdd.com/wp-content/uploads/2018/10/MaRS_ Impact_Report_2018.pdf (accessed on 25 April 2019).

61. Ryan, S.; Young, M. Social impact bonds: The next horizon of privatization. Stud. Political Econ. 2018, 99, 42-58. [CrossRef]

62. Bridges Ventures. Ways to Wellness SIB. Available online: https://www.bigsocietycapital.com/file/1639/ download?token=CqYjHZf_ (accessed on 25 April 2019).

63. Commissioning Better Outcomes (CBO). Ways to Wellness Social Impact Bond: The UK's First Health SIB. Ways to Wellness Deep Dive Report. Available online: https://www.biglotteryfund.org.uk/-/media/Files/ Programme\%20Documents/Commissioning\%20Better\%20Outcomes/CBO_ways_to_wellness_report.pdf (accessed on 25 April 2019). 
64. Commissioning Better Outcomes (CBO). Update Report. Available online: https://www.biglotteryfund.org. uk/-/media/Files/Programme\%20Documents/Commissioning\%20Better\%20Outcomes/CBO\%20Update\% 20Report_Full\%20Report.pdf (accessed on 25 April 2019).

65. Tan, S.; Fraser, A.; Giacomantonio, C.; Kruithof, K.; Sim, M.; Lagarde, M.; Disley, E.; Rubin, J.; Mays, N. An Evaluation of Social Impact Bonds in Health and Social Care: Interim Report. Available online: https:/piru.lshtm.ac.uk/assets/files/Trailblazer\%20SIBs\%20interim\%20report\%20March\%202015, \%20for\%20publication\%20on\%20PIRU\%20siteapril\%20amendedpdf11may.pdf (accessed on 25 April 2019).

66. GoLab. Mental Health and Employment Partnership (Staffordshire, Haringey \& Tower Hamlets). Available online: https://golab.bsg.ox.ac.uk/knowledge/case-studies/mhep/pdf/ (accessed on 25 April 2019).

67. MHEP, Mental Health and Employment Partnership. Mental Health and Employment Partnership. In Depth Review. Available online: https:/www.biglotteryfund.org.uk/-/media/Files/Programme\%20Documents/ Commissioning\%20Better\%200utcomes/comissioning_better_outcomes_in_depth_review.pdf (accessed on 25 April 2019).

68. Commissioning Better Outcome (CBO). Reconnections Social Impact Bond: Reducing Loneliness in Worcestershire. An In-Depth Review. Available online: https://www.bigsocietycapital.com/sites/default/files/ attachments/CBO_In-Depth\%20Reviews_Reconnections.pdf (accessed on 25 April 2019).

69. Gustafsson-Wright, E.; Gardiner, S.; Putcha, V. The Potential And Limitations Of Impact Bonds: Lessons from the First Five Years of Experience Worldwide; Brookings Institute: Washington, DC, USA, 2015.

70. Agapitova, N.; Sanchez, B.; Tinsley, E. Government Support to the Social Enterprise Sector: Comparative Review of Policy Frameworks and Tools. Available online: https://www.innovationpolicyplatform.org/ system/files/SE\%20Policy\%20Note_Jun20.pdf (accessed on 21 May 2019).

71. Government of Canada. The Next Phase of Canada's Economic Action Plan: A Low-Tax Plan for Jobs and Growth. News Release, 7 June 2011. Available online: https://www.canada.ca/en/news/archive/2011/06/ government-canada-reintroduces-next-phase-canada-economic-action-plan-low-tax-plan-jobs-growth. html (accessed on 25 April 2019).

72. Government of Ontario. Piloting Social Impact Bonds in Ontario: The Development Path and Lessons Learned. 12 November 2015. Available online: https://www.ontario.ca/page/piloting-social-impact-bondsontario-development-path-and-lessons-learned (accessed on 25 April 2019).

73. Government of Alberta. Putting Alberta's Growing Savings to Work for Our Future. News Release, 4 March 2014. Available online: https://www.farmingsmarter.com/putting-albertas-growing-savings-workfuture/(accessed on 25 April 2019).

74. Department of Finance-Canada. The Next Phase of Canada's Economic Action Plan: A Low-Tax Plan for Jobs and Growth. Department of Finance, Canada. Available online: https://budget.gc.ca/march-mars-2011/ plan/Budget2011-eng.pdf (accessed on 25 April 2019).

75. Echenberg, H. Government of Canada and Social Finance. Available online: https://lop.parl.ca/staticfiles/ PublicWebsite/Home/ResearchPublications/BackgroundPapers/PDF/2015-140-e.pdf (accessed on 21 May 2019).

76. Albertson, K.; Fox, C. Payment by Results and Social Impact Bonds: Outcome-Based Payment Systems in the UK and US; Policy Press: Chicago, IL, USA, 2018.

77. HM Government. Growing the Social Investment Market: A Vision and Strategy; HM Government: London, UK, 2011. Available online: https://assets.publishing.service.gov.uk/government/uploads/system/uploads/ attachment_data/file/61185/404970_SocialInvestmentMarket_acc.pdf (accessed on 25 April 2019).

78. Big Lottery Fund. About Commissioning Better Outcomes and the Social Outcomes Fund. Available online: https://assets.publishing.service.gov.uk/government/uploads/system/uploads/attachment_data/file/ 261051/CBO_guide.pdf (accessed on 25 April 2019).

79. Cooper, C.; Graham, C.; Himick, D. Social impact bonds: The securitization of the homeless. Account. Organ. Soc. 2016, 55, 63-82. [CrossRef]

80. Sinclair, S.; McHugh, N.; Roy, M.J. Social innovation, financialisation and commodification: A critique of social impact bonds. J. Econ. Policy Reform 2019, 1-17. [CrossRef]

81. Tse, A.E.; Warner, M.E. The razor's edge: Social impact bonds and the financialization of early childhood services. J. Urban Aff. 2018, 1-17. [CrossRef] 
82. Giantris, K.; Pinakiewicz, B. Pay for success: Understanding the risk trade-offs. Community Dev. Invest. Rev. 2013, 9, 35-39.

83. Child, C.; Gibbs, B.G.; Rowley, K.J. Paying for success: An appraisal of social impact bonds. Glob. Econ. Manag. Rev. 2016, 21,36-45. [CrossRef] 